\title{
Carriage and transmission of group B streptococci among STD clinic patients
}

\author{
D H JACKSON,* S M HINDER, † J STRINGER, ‡ AND C S F EASMON $\S$
}

From the Departments of *Genitourinary Medicine and + Medical Microbiology, Basingstoke District Hospital, Hampshire; the $¥$ Division of Hospital Infection, Central Public Health Laboratory, London; and the §Department of Medical Microbiology, St Mary's Hospital Medical School, London

SUMMARY High rates of carriage of group B streptococci were found among men (38\%) and women $(\mathbf{4 2} \cdot \mathbf{3 \%})$ attending a clinic for sexually transmitted diseases. Swabs from the perineal/ anorectal area gave the highest isolation rate and those from the urethra the lowest. The subpreputial sac was an important site for carriage of the organism, and there was a strong association between streptococcal isolation and balanitis. Of 92 couples studied, neither partner was colonised with group B streptococci in 36. In a further 36 one or other was colonised and in 20 both were colonised. Serotyping and phage typing showed that only three of these 20 couples were colonised with similar strains of the organism.

\section{Introduction}

Because of the importance of group B streptococci in neonatal sepsis and the relationship between maternal carriage and the early onset of infection ${ }^{1}$ most work on the epidemiology of the organism has concentrated on women and babies. Until recently the lack of a suitable typing system hampered any epidemiological studies. The work of Stringer ${ }^{2}$ on the phage typing of group B streptococci has remedied this situation. Very little attention has been paid to male carriage and the role of sexual transmission in the epidemiology of this organism.

Although group B streptococci are found in the female genital tract, the work of Kexel and Beck ${ }^{3}$ and Easmon and co-workers ${ }^{4}$ has suggested that the perineal skin may be the primary source of carriage rather than either the genital or gastrointestinal tract. Where different populations have been compared the carriage rates among patients attending sexually transmitted disease clinics have been among the highest. ${ }^{5}$ This has raised the possibility that sexual transmission may play a part in its epidemiology. Weindling and co-writers ${ }^{6}$ have recently shown that husbands and wives colonised by the organism carry identical serotypes and phage types.

Address for reprints: Dr C S F Easmon, Department of Medical Microbiology, Wright-Fleming Institute, St Mary's Hospital Medical School, London W2 IPG;

Accepted for publication 29 May 1982
In this study we examined in detail carriage of group B streptococci in multiple sites in men and women attending a clinic for sexually transmitted disease (STD) and related carriage rates to the presence of a recognised STD. Using phage typing we also looked for evidence of transmission of the organism between sexual partners and attempted to relate this to the stability of the relationship.

\section{Patients and methods}

Patients attending a clinic for sexually transmitted diseases either for the first time or for re-examination were included in the survey. Samples for this study were taken after those for other routine diagnostic investigations. In male patients three plain cottonwool swabs were used to sample the endourethra, the preputial sac (coronal sulcus in circumcised patients), and perineum. In female patients urethral, high vaginal, and perineal swabs were taken. In men and women who had a proctoscopic examination rectal swabs were substituted for perineal swabs. Sexual partners were identified later from the case notes.

SWABBING PROCEDURE

Swabs were incubated overnight at $37^{\circ} \mathrm{C}$ in Todd Hewitt broth supplemented with $0.5 \%(\mathrm{v} / \mathrm{v})$ horse blood, gentamicin sulphate $4 \mathrm{mg} / \mathrm{l}$, and nalidixic acid $15 \mathrm{mg} / \mathrm{l}$. Subcultures were then made on blood agar and Islam's starch serum agar $^{7}$ and incubated anaerobically for 24 hours at $37^{\circ} \mathrm{C}$ using the Gaspak 
system (BBL). Gram-positive catalase-negative organisms which produced haemolysis on blood agar or orange-yellow pigmentation on Islam's medium were serogrouped by the Streptex method (Wellcome Reagents). Group B streptococci were serotyped and selected strains also phage typed.

\section{DIAGNOSIS OF STD}

Neisseria gonorrhoeae was cultured on Neisseria isolation medium (Difco) supplemented with antibiotics. Oxidase-positive Gram-negative cocci were identified by fermentation and immunofluorescence reactions. Post-gonococcal urethritis was defined as a urethritis persisting seven days after treatment. Non-specific urethritis was defined microscopically as a mean minimum of 10 polymorphonuclear leucocytes/high power field with no microscopical or cultural evidence of a specific pathogen. Chlamydial cultures were not performed. Gardnerella vaginalis and Trichomonas vaginalis were diagnosed microscopically by the presence of clue cells and large numbers of small Gram variable bacilli and trichomonads respectively. Candida spp were diagnosed primarily by microscopy although in some cases growth was noted on the gonococcal isolation plates. Herpes genitalis was confirmed by the isolation of herpes simplex virus.

\section{Results}

Carriage of group B streptococci in male patients is shown in table $I$. Of the 132 patients sampled, 50 $(37.9 \%)$ were carriers. Of these 50 men, $39(78 \%)$ had positive results on perineal or rectal swabs or both. This combination gave the highest rate of positive results and was the only site of carriage in 11 men. No one site gave a positive result in all cases. Preputial and urethral carriage was lower in men with no clinical or microbiological evidence of STD. Non-specific balanitis and candidal balanitis were both associated with a higher isolation rate of group B streptococci from the subpreputial sac and urethra.

Female carriage of the organism is shown in table II. The overall carriage rate $(69 / 163,42 \cdot 3 \%)$ was similar to that found for men. The proportion of positive results on perineal/anorectal swabs was,

TABLE I Isolation of group B streptococci from various sites in men

\begin{tabular}{|c|c|c|c|c|c|}
\hline \multirow{2}{*}{$\begin{array}{l}\text { Clinical findings } \\
\text { and diagnosis* }\end{array}$} & \multirow{2}{*}{$\begin{array}{l}\text { No of } \\
\text { patients }\end{array}$} & \multirow{2}{*}{$\begin{array}{l}\text { Total No } \\
\text { culture-positive (\%) }\end{array}$} & \multicolumn{3}{|c|}{ No (\%) of sites giving positive culture result: } \\
\hline & & & Urethra & Subpreputial sac & Perineum (rectum) \\
\hline $\begin{array}{l}\text { No abnormality } \\
\text { Clinical abnormality } \\
\text { Total }\end{array}$ & $\begin{array}{r}27 \\
105 \\
132\end{array}$ & $\begin{array}{r}8(29 \cdot 6) \\
42(40 \cdot 0) \\
50(37 \cdot 9)\end{array}$ & $\begin{array}{r}4(14 \cdot 8) \\
27(25 \cdot 7) \\
31(23 \cdot 5)\end{array}$ & $\begin{aligned} 2 & (7 \cdot 4) \\
31 & (29 \cdot 5) \\
33 & (25 \cdot 0)\end{aligned}$ & $\begin{array}{r}7(25 \cdot 9) \\
32(30 \cdot 5) \\
39(29 \cdot 5)\end{array}$ \\
\hline $\begin{array}{l}\text { Post gonococcal } \\
\text { urethritis } \\
\text { Gonorrhoea }\end{array}$ & $\begin{array}{l}42 \\
29\end{array}$ & $\begin{array}{l}16(38 \cdot 1) \\
10(34 \cdot 5)\end{array}$ & $\begin{array}{l}9(21 \cdot 4) \\
7(24 \cdot 1)\end{array}$ & $\begin{array}{r}11(26 \cdot 2) \\
6(20 \cdot 7)\end{array}$ & $\begin{array}{r}10(23 \cdot 9) \\
8(27 \cdot 6)\end{array}$ \\
\hline $\begin{array}{l}\text { Non-specific } \\
\text { balanitis } \\
\text { Herpes genitalis }\end{array}$ & 20 & $12(60 \cdot 0)$ & $10(50 \cdot 0)$ & $11(55 \cdot 0)$ & $10(50 \cdot 0)$ \\
\hline $\begin{array}{l}\text { and warts } \\
\text { Candidal balanitis }\end{array}$ & $\begin{array}{l}17 \\
11\end{array}$ & $\begin{array}{l}7(41 \cdot 2) \\
5(45 \cdot 5)\end{array}$ & $\begin{array}{l}5(29 \cdot 4) \\
4(36 \cdot 4)\end{array}$ & $\begin{array}{l}5(29 \cdot 4) \\
5(45 \cdot 5)\end{array}$ & $\begin{array}{l}5(29 \cdot 4) \\
3(27 \cdot 3)\end{array}$ \\
\hline
\end{tabular}

*Some patients had more than one condition

TABLE II Isolation of group B streptococci from various sites in women

\begin{tabular}{|c|c|c|c|c|c|}
\hline \multirow{2}{*}{$\begin{array}{l}\text { Clinical findings } \\
\text { and diagnosis* }\end{array}$} & \multirow{2}{*}{$\begin{array}{l}\text { No of } \\
\text { patients }\end{array}$} & \multirow{2}{*}{$\begin{array}{l}\text { Total No } \\
\text { culture-positive (\%) }\end{array}$} & \multicolumn{3}{|c|}{ No (\%) of sites giving positive culture result: } \\
\hline & & & Urethra & Vagina & Perineum (rectum) \\
\hline $\begin{array}{l}\text { No abnormality } \\
\text { Clinical abnormality } \\
\text { Total } \\
G \text { vaginalis }\end{array}$ & $\begin{array}{r}33 \\
130 \\
163\end{array}$ & $\begin{array}{l}15(45 \cdot 5) \\
54(41 \cdot 5) \\
69(42 \cdot 3)\end{array}$ & $\begin{array}{r}6(18 \cdot 2) \\
37(28 \cdot 5) \\
43(26 \cdot 4)\end{array}$ & $\begin{array}{r}7(21 \cdot 2) \\
41(31 \cdot 5) \\
48(29 \cdot 4)\end{array}$ & $\begin{array}{l}15(45 \cdot 5) \\
50(38 \cdot 5) \\
65(39 \cdot 9)\end{array}$ \\
\hline $\begin{array}{l}\text { infection } \\
\text { Gonorrhoea } \\
\text { Candidal infection } \\
\text { Herpes genitalis }\end{array}$ & $\begin{array}{l}55 \\
36 \\
35\end{array}$ & $\begin{array}{l}19(34 \cdot 5) \\
16(44 \cdot 4) \\
15(42 \cdot 9)\end{array}$ & $\begin{array}{r}9(16 \cdot 4) \\
10(27 \cdot 8) \\
13(37 \cdot 1)\end{array}$ & $\begin{array}{l}13(23 \cdot 6) \\
11(30 \cdot 6) \\
12(34 \cdot 3)\end{array}$ & $\begin{array}{l}18(32 \cdot 7) \\
14(38 \cdot 9) \\
14(40 \cdot 0)\end{array}$ \\
\hline $\begin{array}{l}\text { and warts } \\
\text { Non-specific }\end{array}$ & 26 & $11(42 \cdot 3)$ & $9(34 \cdot 6)$ & $11(42 \cdot 3)$ & $10(38 \cdot 5)$ \\
\hline $\begin{array}{l}\text { vaginitist } \\
T \text { vaginalis }\end{array}$ & 11 & $5(45 \cdot 4)$ & $4(36 \cdot 4)$ & $5(45 \cdot 4)$ & $5(45 \cdot 4)$ \\
\hline infection & 11 & $4(36 \cdot 4)$ & $4(36 \cdot 4)$ & $4(36 \cdot 4)$ & $4(36 \cdot 4)$ \\
\hline
\end{tabular}

* Some patients had more than one condition

tNo herpes simplex, $G$ vaginalis, $T$ vaginalis, or candidal infection 
however, rather higher $(65 / 69,94 \cdot 2 \%)$. Urethral and vaginal carriage was generally higher in women with confirmed STD than in those who had no other detectable infection. The exception to this was $G$ vaginalis infection, in which the urethral and vaginal carriage rates of group B streptococci were low.

\section{SEXUAL TRANSMISSION}

Ninety-two couples known to have had sexual intercourse together were studied. If an individual had more than one partner each of the relationships was regarded as "a couple" for this study. In 56 of the 92 couples either one or both partners were colonised with group B streptococci (11/56 men, 25/56 women, $20 / 56$ both partners). Isolates of the organism from 18 of the 20 couples where both partners were colonised were serotyped and phage typed. In only three of these couples did serotyping and phage typing suggest that sexual transmission could have taken place (table III). There was no association between the stability of the relationship and the finding of identical serotypes and phage types in sexual partners.

\section{Discussion}

Direct comparisons of carriage rates of group B streptococci in different surveys are often difficult because of variations in sampling methods and bacteriological techniques. Several studies have shown that colonisation by the organism is very high among those attending clinics for sexually transmitted diseases. ${ }^{58}$ Our female carriage rate of $42 \cdot 3 \%$ was similar to that of $37 \cdot 6 \%$ reported by Embil and co-workers ${ }^{5}$ and that of $36 \cdot 1 \%$ by Finch and coworkers. ${ }^{8}$ Although this high carriage rate in women and the equally high rate in men might suggest sexual transmission of the organism, this was not substantiated by a more detailed investigation of the 92 couples studied. Whereas in $56(60.9 \%)$ of these the organism was isolated in one partner, in only three $(5 \cdot 3 \%)$ were both partners colonised by identical serotypes and phage types. This occurred despite the sampling of multiple sites, the use of broth enrichment techniques, and the search for more than one type at each site.

Weindling and co-workers ${ }^{6}$ have shown that family groups in general and husbands and wives in particular tend to be colonised with group B streptococci of the same serotype and phage type. Although their sample population was a similar size to our own, many of the couples whom we studied would not have had stable relationships. We did not, however, find any link between such stability and colonisation with the same organism. Colonisation with one strain may prevent further colonisation with different strains.

The primary site of colonisation is not known. Claims have been made for the genital tract, ${ }^{1}$ gastrointestinal tract, ${ }^{9}$ urethra, ${ }^{10}$ and perineum. ${ }^{4}$ In both men and women the organism was isolated more frequently from perianal/rectal swabs than from material from either the vagina in women, the subpreputial sac in men, or the urethra in both. In men the distribution of the organism among the three sites was more even than in women, where rectal/perineal colonisation was found in 65 of the 69 carriers. Although we did find more than one serotype in the

TABLE III Phage types and serotypes in 18 couples in which both partners were colonised with group B streptococci

\begin{tabular}{|c|c|c|c|c|}
\hline \multirow[b]{2}{*}{ Couple No } & \multicolumn{2}{|l|}{ Men } & \multicolumn{2}{|l|}{ Women } \\
\hline & Serotype & Phage type & Serotype & Phage type \\
\hline & & & lc & $\mathrm{N} / \mathrm{T}$ \\
\hline 1 & II R & $\mathrm{N} / \mathrm{T}$ & III $\mathrm{R}$ & 12 \\
\hline 2 & Ic & $\mathrm{N} / \mathrm{T}$ & Ic & 17182629 \\
\hline 3 & III $\mathrm{R}$ & 12 & lc & 171826 \\
\hline 4 & Ic & $15 \quad 1819262829$ & lic & 171826 \\
\hline $5^{*}$ & Ic & 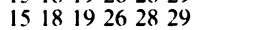 & 心 & 151819262829 \\
\hline 6 & II $\mathrm{R}$ & $\mathrm{N} / \mathrm{T}$ & II & 121314163031 \\
\hline 7 & III $\mathrm{R}$ & 12 & iil $\mathrm{R}$ & 2731 \\
\hline 8 & II $\mathrm{R}$ & $\mathrm{N} / \mathrm{T}$ & III $\mathrm{R}$ & 12 \\
\hline 9 & II $\mathrm{R}$ & $1216 \quad 172024 \quad 2829$ & III $\mathrm{R}$ & 2731 \\
\hline 10 & II & 20 & iI $\mathrm{R}$ & 1220 \\
\hline $11^{*}$ & Ic & 1517181926282930 & li & 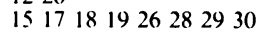 \\
\hline $12^{*}$ & $\mathrm{II} / \mathrm{IC}$ & $\mathrm{N} / \mathrm{T}$ & $1 / \mathrm{lc}$ & $\mathrm{N} / \mathrm{T}$ \\
\hline 13 & III & $\mathrm{N} / \mathrm{T}$ & $\mathrm{R}$ & 712 \\
\hline 14 & II $/ \mathrm{Ic}$ & 71220262930 & la & $\begin{array}{llllllll}15 & 17 & 18 & 19 & 26 & 28 & 29 & 30\end{array}$ \\
\hline 15 & $\mathrm{~N} / \mathrm{T}$ & 3814 & Ic & 314 \\
\hline 16 & $\mathrm{II} / \mathrm{IC}$ & 71220262930 & Ia & $\begin{array}{lllllllll}15 & 17 & 18 & 19 & 26 & 28 & 29 & 30\end{array}$ \\
\hline 17 & II $/ \mathrm{IC}$ & $\mathrm{N} / \mathrm{T}$ & $\mathrm{R}$ & 1122731 \\
\hline 18 & II $\mathrm{R}$ & 7122731 & $\mathrm{R}$ & 1122731 \\
\hline
\end{tabular}

* Likely sexual transmission of group B streptococci

$\mathrm{N} / \mathrm{T}=$ not typeable 
same individual (both in a single site or in different sites) this was not common.

The only strong association found was between the isolation of group B streptococci and balanitis, in which $12(60 \%)$ of the 20 cases carrying the organism in the urethra or subpreputially. This association merits further investigation. ${ }^{11}$ Because of the small numbers involved, the importance of other observations such as the lower carriage rates in women with infections due to $G$ vaginalis or $T$ vaginalis and in men with gonorrhoea uncomplicated by postgonococcal urethritis is impossible to determine. Christensen and co-workers ${ }^{12}$ found that the carriage rate was higher in those with gonorrhoea while Wallin and Forsgren ${ }^{13}$ and Embil and co-workers 5 did not.

The work was supported by the Medical Research Council.

\section{References}

1. Parker MT. Infections with group B streptococci. J Antimicrob Chemother 1979:5 suppl A:27-37.
2. Stringer $\mathrm{J}$. The development of a phage-typing wstem for group B streptococci. J.Med Microbiol 1980: 13:133-44.

3. Kexel G, Beck KJ. Untersuchen über die Haufigkeit der B-Streptokokken in Wochenbett. Geburtschilfe und Frauenheilkunde 1965:25: 1078-25

4. Easmon CSF, Hastings MJG. Clare AJ, et al. Nosocomial transmission of group B streptococii. Br Med J 1981;283: 459-61.

5. Embil JA, Martin TR, Hanset NH, MacDonald SW Manvel FR. Group B beta-haemolytic streptococci in the female genital tract: a study of four clinic populations. Br J Obstet Gynaecol 1978; 85: 783-6.

6. Weindling AM, Hawkins JM. Coombes MA. Stringer J. Colonisation of babies and their families by group B streptococci. Br Med J 1981: ii: 1503-5.

7. Islam AKMS. Rapid recognition of group B streptococci. Lancet 1977; i: 256-7.

8. Finch RG, French GL. Phillips 1. Group B streptococsi in the female genital tract. $B r$ 1ed $J$ 1976; i: 1245-7.

9. Badri MS, Zawaneh S. Cruz AC. et al. Rectal colonisation with group B streptococius: relation to vaginal colonisation in pregnant women. J Infect Dis 1977; 135: 108-12.

10. Christensen KK. Ripa T. Agrup G, Christensen P. Group B streptococci in human urethral and cervical specimens. Scand $J$ Infect Dis 1976;8: 75-8.

11. Brooke, 1. Group B heta-haemolytic streptococi causing balanitis. South lled J 1980:73:1095.

12. Christensen KK. Christensen P-Ftamhole L, Ripa T. Frequency of streptociccis of groups A, B, C, D and G in urethra and cervix swab specimens from patients with suspected sonscoccal infection. tita Pathol Microbiol Scand $B$ 19-4:82: 470-4.

13. Wallin J. Forseren A. Ciroun B streptococci in venereal discias clinic patients. $B r . J$ liner Dis 1975;51:401-4. 